\title{
Utilization of household food waste for the production of ethanol at high dry material content
}

\author{
Leonidas Matsakas ${ }^{1,3}$, Dimitris Kekos ${ }^{1}$, Maria Loizidou² and Paul Christakopoulos ${ }^{3^{*}}$
}

\begin{abstract}
Background: Environmental issues and shortage of fossil fuels have turned the public interest to the utilization of renewable, environmentally friendly fuels, such as ethanol. In order to minimize the competition between fuels and food production, researchers are focusing their efforts to the utilization of wastes and by-products as raw materials for the production of ethanol. household food wastes are being produced in great quantities in European Union and their handling can be a challenge. Moreover, their disposal can cause severe environmental issues (for example emission of greenhouse gasses). On the other hand, they contain significant amounts of sugars (both soluble and insoluble) and they can be used as raw material for the production of ethanol.

Results: Household food wastes were utilized as raw material for the production of ethanol at high dry material consistencies. A distinct liquefaction/saccharification step has been included to the process, which rapidly reduced the viscosity of the high solid content substrate, resulting in better mixing of the fermenting microorganism. This step had a positive effect in both ethanol production and productivity, leading to a significant increase in both values, which was up to $40.81 \%$ and 4.46 fold, respectively. Remaining solids (residue) after fermentation at $45 \%$ $\mathrm{w} / \mathrm{v}$ dry material (which contained also the unhydrolyzed fraction of cellulose), were subjected to a hydrothermal pretreatment in order to be utilized as raw material for a subsequent ethanol fermentation. This led to an increase of $13.16 \%$ in the ethanol production levels achieving a final ethanol yield of $107.58 \mathrm{~g} / \mathrm{kg}$ dry material.
\end{abstract}

Conclusions: In conclusion, the ability of utilizing household food waste for the production of ethanol at elevated dry material content has been demonstrated. A separate liquefaction/saccharification process can increase both ethanol production and productivity. Finally, subsequent fermentation of the remaining solids could lead to an increase of the overall ethanol production yield.

Keywords: Ethanol, Liquefaction, Saccharification, Household food waste, Residue solids, Subsequent fermentation, Saccharomyces cerevisiae

\section{Background}

The environmental crisis and the shortage of fossil fuels have turned public attention to the utilization of other forms of energy, which are environmentally friendly and renewable, such as bio-ethanol [1,2]. During recent years research has focused on the so-called second-generation biofuels, where wastes or by-products are utilized as raw

\footnotetext{
* Correspondence: paul.christakopoulos@ltu.se

${ }^{3}$ Department of Civil, Biochemical and Chemical Process Engineering, Division of Sustainable Process Engineering, Environmental and Natural Resources Engineering, Luleå University of Technology, SE 97187 Luleå, Sweden

Full list of author information is available at the end of the article
}

material, compared to the first-generation biofuels where sugars and starch were utilized. This way, increasing pubic concerns about utilizing food sources for the production of biofuels can be solved, as the utilization of either sugars or corn for the production of biofuels have contributed to the increase of their price worldwide, resulting in severe problems for the poorer countries. All these concerns led to a rapid increase in research to utilize low-cost by-products and wastes as raw material [3-6]. Lignocellulosic biomass represents great potential to be utilized as raw material due to the high amounts produced every year [7], and can be derived from woody or agricultural residues such as wheat straw, corn cobs, 
bagasse, rice straw, et cetera. The main challenge of utilizing lignocellulosic biomass is efficient sugar release, mainly from cellulose. In order to achieve this, an efficient pretreatment step followed by enzymatic hydrolysis have to be applied $[8,9]$. Generally, the pretreatment process contributes to increased costs of the whole process [10].

A different and alternative source of raw material for the production of biofuels could be the utilization of municipal organic wastes and especially household food wastes (HFW). Taking into account that the total quantity of HFW for the EU-27 during 2006 is estimated to be $37.7 \mathrm{Mt}$, which accounts for approximately $76 \mathrm{~kg}$ per capita and represents $42 \%$ of the total amount of food wastes generated in the EU [11], it is clear that they represent a challenge concerning their disposal, as well as an attractive raw material for the production of biofuels. Moreover, there is a trend of increasing the quantities of total food wastes produced (which are coming from both domestic, manufacture, food service/catering and retail/ wholesale sectors), which, according to the European Commission (EC), will rise from 89.3 Mt in 2006 to 126.2 Mt by 2020 [11]. A common practice of HFW management is landfill disposal, which is causing severe environmental problems (such as greenhouse gas emissions) and shortage of disposal places [6,12,13]. Other practices are utilization as animal feed (which can raise hygiene issues) and soil conditioners-fertilizers (which can cause severe pollution to surface and underground water) $[6,12,14]$. Alternatively HFW can be used for the production of bio-based (green) chemicals and bio-energy (for example, biogas and ethanol) [15,16]. Until now, most of the research dedicated to HFW utilization was focused on biogas production.

Utilization of HFW as raw material represents a great challenge, as both the collection of generated HFW from multiple places [13] and post-collection treatment are difficult processes. Moisture and soluble sugars can make HFW an easy target for microorganisms, leading to their severe degradation. Another challenge is the heterogeneity that HFW present $[13,14]$, which is highly affected by the source from which the wastes are derived. Nutritional habits and season of collection can also affect the composition of the HFW. Generally, fruits and vegetables represent a significant portion of the wastes $[6,17]$. Finally, one important issue to be solved is the proper education of the public in order to achieve low presence of contaminants (for example, plastics, metal et cetera) during source separation of HFW.

Concerning the utilization of HFW, there are some reports where different types of pretreatment, such as acid, alkali and thermal, have been used in order to increase cellulose digestibility [18-20]. Despite the fact that a pretreatment process can increase digestibility of cellulose, the soluble sugars can be degraded forming various inhibitors (such as furfural), especially if the pretreatment is performed at harsher conditions and in the presence of alkali.

The aim of this work was the utilization of sourceseparated HFW for the production of ethanol, at high dry material (DM) levels in order to achieve high ethanol production. Utilization of HFW at high DM levels results in a very viscous mash, where only solid-state cultivation can be applied, which presents many disadvantages including difficulties for process scaling-up and ethanol recovery [21]. In order to overcome this obstacle, an enzymatic liquefaction/saccharification process prior to fermentation, employing commercial cellulases solution (Celluclast ${ }^{\circ} 1.5 \mathrm{~L}$ and Novozym 188) was applied. During this process the viscosity of the high solid-content substrate was rapidly reduced, enabling submerged fermentation. No pretreatment prior to enzymatic saccharification was applied, in order to minimize the soluble sugar degradation. Finally, in order to maximize the ethanol yield a subsequent treatment and fermentation of the remaining solids (residue) was applied. During recent years, a new gravimetric mixing system has been successfully applied for the liquefaction of pretreated lignocellulosic feedstock at high DM content and was used in the present study $[22,23]$.

\section{Results and discussion}

\section{Fermentation of saccharified HFW}

Table 1 shows the HFW composition obtained. HFW has potential to be utilized as raw material, as cellulose content is quite high and soluble sugars, such as glucose, fructose and sucrose are present and can be readily converted to ethanol. According to the literature, most

Table 1 Composition of HFW

\begin{tabular}{lc}
\hline Fraction & \% w/w \\
\hline Soluble & $33.81 \pm 0.42$ \\
Glucose & $4.39 \pm 0.20$ \\
Fructose & $3.47 \pm 0.12$ \\
Sucrose & $4.38 \pm 0.10$ \\
Total reducing sugars & $12.54 \pm 0.93$ \\
Protein & $0.54 \pm 0.01$ \\
Fats & $11.91 \pm 0.68$ \\
Crude protein & $10.51 \pm 0.37$ \\
Pectin & $3.92 \pm 0.33$ \\
Cellulose & $18.30 \pm 0.19$ \\
Hemicellulose & $7.55 \pm 0.39$ \\
Klason lignin & $2.16 \pm 0.25$ \\
Ash & $11.03 \pm 0.42$ \\
\hline
\end{tabular}

Initial moisture content was $1.03 \pm 0.20 \% \mathrm{w} / \mathrm{w}$.

The values are given as mean \pm SD. 
researchers are analyzing food wastes by measuring the chemical oxygen demand (COD), biological oxygen demand (BOD), volatile solids (VS) et cetera [18-20,24-26], especially when they are utilized for biogas production. Though these values can provide important information about the raw material, for the ethanol production processes it is more important to know the proportion of soluble and insoluble sugars, as well as the type of insoluble polysaccharides, in order to apply the most appropriate enzymatic hydrolysis treatment.

Composition of food wastes can present a wide variety. Zhang and Richard [27] utilized a food-waste sample from a composting site of a University with a composition of $23.3 \% \mathrm{w} / \mathrm{w}$ total reducing sugars, $34.8 \% \mathrm{w} / \mathrm{w}$ starch and $1.6 \% \mathrm{w} / \mathrm{w}$ fibers and employed mainly amylases for its saccharification. Moon et al. [6] mentioned a high starch $(30.1 \% \mathrm{w} / \mathrm{w})$ and fiber content $(14.9 \% \mathrm{w} / \mathrm{w})$ with total reducing sugars of $17.6 \% \mathrm{w} / \mathrm{w}$ making it necessary to utilize both amylases and cellulases to treat it, whereas a high starch content $(63.9 \% \mathrm{w} / \mathrm{w})$ combined with low cellulose amounts was reported by Yan et al. [12] for the HFW sample that was used in their experiments.

The liquefaction/saccharification process was performed for $8 \mathrm{~h}$ at an initial DM content of $45 \% \mathrm{w} / \mathrm{v}$ followed by fermentation at two different initial DM contents $(35 \%$ and $45 \% \mathrm{w} / \mathrm{v})$. As can been evidenced from Figure 1, HFW was fully liquified after 8 hours of enzymatic treatment. This fact is also supported by the difference in the viscosity measured at an angular velocity of $10 \mathrm{rad} / \mathrm{s}$ before and after the enzymatic treatment, which decreased from $2790 \mathrm{~Pa} \cdot \mathrm{s}$ to $67.5 \mathrm{~Pa} \cdot \mathrm{s}$, respectively. Maximum ethanol production in both DM contents was observed after $15 \mathrm{~h}$ of fermentation (Figure 2) and found to be $34.85 \mathrm{~g} / \mathrm{L}(35 \% \mathrm{w} / \mathrm{v} \mathrm{DM})$ and $42.78 \mathrm{~g} / \mathrm{L}(45 \% \mathrm{w} / \mathrm{v}$ DM) with a volumetric productivity of $2.32 \mathrm{~g} / \mathrm{L} \cdot \mathrm{h}$ (35\% w/v DM) and $2.85 \mathrm{~g} / \mathrm{L} \cdot \mathrm{h}(45 \% \mathrm{w} / \mathrm{v} \mathrm{DM})$ (Table 2). Cellulose hydrolysis at the end of the fermentation reached $50.27 \%$ of the initial cellulose content in raw material. Considering this, the obtained yields $\left(Y_{p / s}\right)$ were $0.443 \mathrm{~g} / \mathrm{g}$ and $0.423 \mathrm{~g} / \mathrm{g}$ at $35 \%$ and $45 \% \mathrm{w} / \mathrm{v}$ DM respectively. The highest ethanol yield obtained when the fermentation was performed at 35\% w/v DM could be attributed to the better mixing conditions.

With no use of the separate liquefaction step the ethanol production reduced by $28.98 \%$ and $8.49 \%$ when fermentation performed at $35 \%$ and $45 \% \mathrm{w} / \mathrm{v}$ initial DM, respectively. The use of the liquefaction/saccharification step was also associated with a significant increase in ethanol volumetric productivities (Table 2), mainly due to the partial cellulose hydrolysis which enabled reduction of viscosity and better mixing conditions of the fermenting raw material [28]. Same enhancement in ethanol production efficiency was also demonstrated by Kim et al. [25], who observed an increase in ethanol yield from $0.31 \mathrm{~g} / \mathrm{g}$ to $0.43 \mathrm{~g} / \mathrm{g}$ total solid when applying a Separate Hydrolysis and Fermentation (SHF) process instead of Simultaneous Saccharification and Fermantation (SSF) process on cafeteria food waste. Manzanares et al. [29] also found that with increasing initial DM content, a separate saccharification step improves fermentation of liquid hot waterpretreated olive-pruning biomass. Finally, Hoyer et al. [30] reported that with increasing DM content, even $4 \mathrm{~h}$ of saccharification could significantly improve fermentation of softwoods.

Ethanol production efficiency during this work was higher than that compared to Moon et al. [6] who performed a 3-h liquefaction process of food waste using both carbohydrases and amyloglucosidases where the ethanol production reached $29.1 \mathrm{~g} / \mathrm{L}$ (Table 3). Walker et al. [31] utilized food wastes from starch-containing food and after saccharification with amylases the overall ethanol production was $8 \mathrm{~g} / \mathrm{L}$. Uncu and Cekmecelioglu [14] achieved $32.2 \mathrm{~g} / \mathrm{L}$ ethanol production after $59 \mathrm{~h}$ of fermentation using food wastes treated for $6 \mathrm{~h}$ with amylases. Jeong et al. [32] reached $40.59 \mathrm{~g} / \mathrm{L}$ ethanol production after $24 \mathrm{~h}$ of fermentation on food wastes hydrolyzed for $8 \mathrm{~h}$ with enzymes, using the fermentative microorganism Saccharomyces coreanus. When Pichia stipitis was added as a co-fermenting microorganism, ethanol production increased up to $48.63 \mathrm{~g} / \mathrm{L}$ but the obtained productivities were lower than those of the present work. Cekmecelioglu and \& Uncu [33]

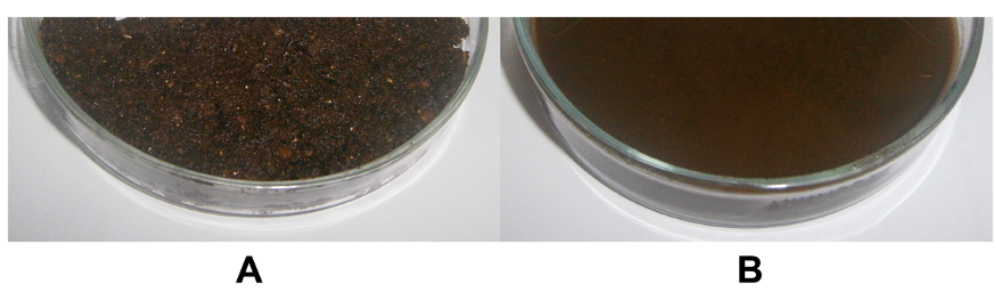

A

B

Figure 1 Effect of enzymatic liquefaction/saccharification on household food wastes (HFW) at 45\% dry material (DM). (A) Prior to liquefaction/saccharification; (B) after 8 h of liquefaction/saccharification. Liquefaction of HFW was conducted for 8 h at an initial DM content of $45 \% \mathrm{w} / \mathrm{v}$ at $50^{\circ} \mathrm{C}$. The enzyme load applied was 10 unit/g DM of a mixture of Celluclast ${ }^{\circledR} 1.5 \mathrm{~L}$ and Novozym 188 at a ratio of 5:1 v/v. 


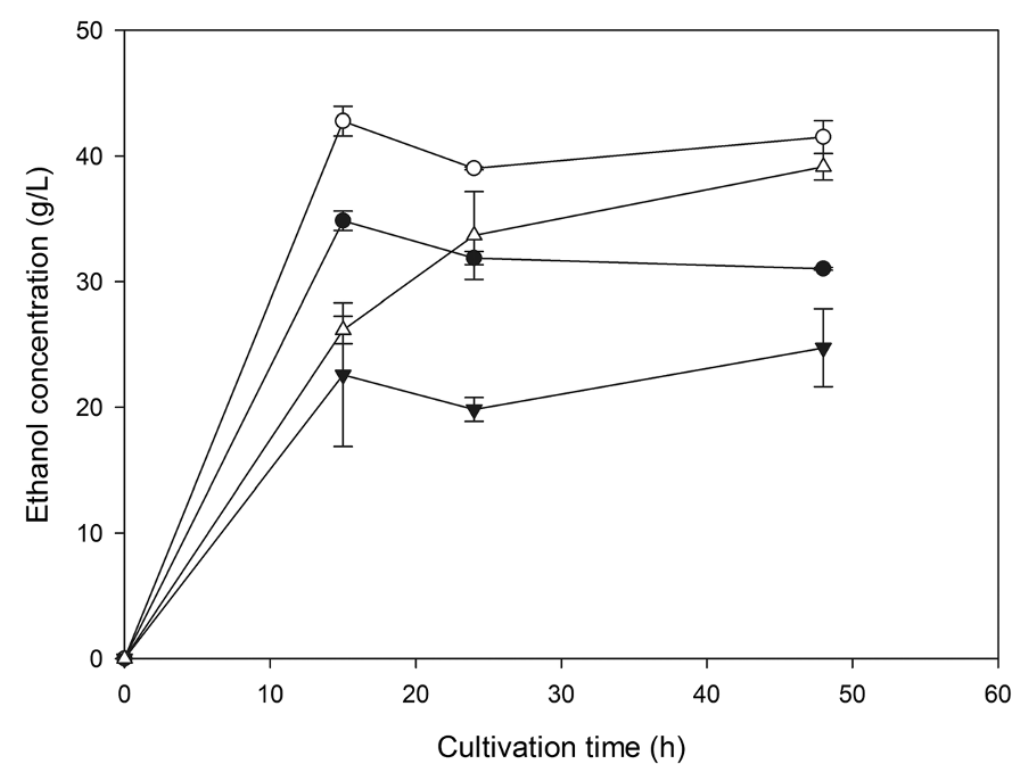

Figure 2 Production of ethanol from liquefied household food waste (HFW). Time course of ethanol production from HFW at 35\% (solid circles) and 45\% (open circles) initial dry material (DM) content with liquefaction/saccharification and at 35\% (solid triangles) and $45 \%$ (open triangles) without liquefaction/saccharification.

reported an ethanol production of $23.3 \mathrm{~g} / \mathrm{L}$ after $48 \mathrm{~h}$ of cultivation on kitchen wastes saccharified for $6 \mathrm{~h}$. Yan et al. [12] reported an ethanol production of $81.5 \mathrm{~g} / \mathrm{L}$ from a saccharified high starch containing raw material (starch content was $63.9 \% \mathrm{w} / \mathrm{w}$ ) using a high glucoamylase load (142.2 unit/g). Finally, Kim et al. [34] achieved $57.5 \mathrm{~g} / \mathrm{L}$ ethanol production after $14 \mathrm{~h}$ of fermentation using starchy food waste saccharified for $4 \mathrm{~h}$ with amylases.

\section{Pretreatment and fermentation of the solid residue}

At the end of the fermentation there is a remaining solid fraction that was not converted to ethanol. This solid fraction contains unhydrolyzed cellulose which practically is lost from the ethanol production process. In order to increase the overall biofuel yield of the raw material's mass, these solids could be further utilized. Some research has proposed the utilization of the remaining solids after fermentation and ethanol distillation for the production of biogas on kitchen waste [35], oat straw [36], wheat straw $[37,38]$ and corn stover [39].

As it is described in the Methods section, after the end of the fermentation at $45 \%$ initial DM the solids were removed from the fermentation broth. This solid fraction contains the unhydrolyzed cellulose fraction, which could be further utilized for the production of ethanol in order to increase the overall production yield. The high degree of recalcitrance of this fraction [40] makes a pretreatment process prior to liquefaction/saccharifiacation necessary. During this study, hydrothermal pretreatment with the presence of acetic acid as a catalyst was applied [41,42]. After the pretreatment, solids were separated from the liquid fraction and washed with distilled water in order to remove the catalyst and other inhibitors formed during pretreatment. Inhibitor removal is necessary in order to decrease the stress to the fermenting microorganism, allowing higher fermentation rates and ethanol production efficiency [43-47].

Table 2 Results of ethanol production during cultivation of S. cerevisiae on HFW

\begin{tabular}{|c|c|c|c|c|c|}
\hline $\begin{array}{c}\text { Initial dry material } \\
(\% \mathrm{w} / \mathrm{v})\end{array}$ & $\begin{array}{c}\text { Separate } \\
\text { liquefaction } \\
\text { step }\end{array}$ & $\begin{array}{l}\text { Ethanol production } \\
(\mathrm{g} / \mathrm{L})\end{array}$ & $\begin{array}{l}\text { Ethanol productivity } \\
\qquad(\mathrm{g} / \mathrm{L} \cdot \mathrm{h})\end{array}$ & $\begin{array}{c}\% \text { of the } \\
\text { maximum } \\
\text { theoretical } \\
\text { yield }^{\mathrm{a}}\end{array}$ & $\begin{array}{c}\% \text { of the } \\
\text { maximum } \\
\text { theoretical } \\
\text { yield }^{b}\end{array}$ \\
\hline 35 & + & $34.85 \pm 0.55$ & $2.32 \pm 0.04$ & $59.82 \pm 0.94$ & $159.21 \pm 2.51$ \\
\hline 45 & + & $42.78 \pm 0.83$ & $2.85 \pm 0.06$ & $57.12 \pm 1.10$ & $151.91 \pm 2.93$ \\
\hline 35 & - & $24.75 \pm 2.20$ & $0.52 \pm 0.05$ & $42.48 \pm 3.78$ & $113.07 \pm 10.05$ \\
\hline 45 & - & $39.15 \pm 0.75$ & $0.82 \pm 0.02$ & $52.28 \pm 1.00$ & $139.07 \pm 2.66$ \\
\hline
\end{tabular}

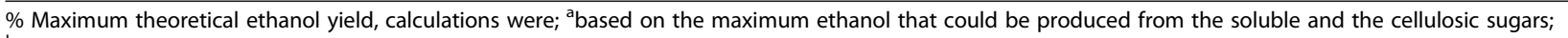
${ }^{b}$ based on the maximum ethanol production from the soluble sugars only.

The values are given as mean \pm SD. 
Table 3 Production of ethanol from food wastes from different sources

\begin{tabular}{|c|c|c|c|c|c|}
\hline \multirow{2}{*}{$\begin{array}{l}\text { Source of food } \\
\text { waste }\end{array}$} & \multicolumn{2}{|c|}{ Carbohydrate content $(\% \mathrm{w} / \mathrm{w})$} & \multicolumn{2}{|c|}{ Ethanol yield parameters } & \multirow[t]{2}{*}{ Reference } \\
\hline & Soluble $^{a}$ & Fiber & Concentration (g/L) & Productivity $(g / L \cdot h)$ & \\
\hline Cafeteria & n.a. & n.a. & n.a. & n.a. & {$[25]$} \\
\hline Cafeteria & 47.7 & 14.9 & 29.1 & 1.94 & [6] \\
\hline Dining center & n.a. & n.a. & 8 & n.a. & [31] \\
\hline Cafeteria and houses & \multicolumn{2}{|c|}{69} & 32.2 & 0.55 & [14] \\
\hline Cafeteria & n.a. & n.a. & 48.63 & 2.03 & [32] \\
\hline Food courts & \multicolumn{2}{|c|}{57.6} & 23.3 & 0.49 & [33] \\
\hline Dining room & 63.9 & 1.98 & 81.5 & 1.36 & [12] \\
\hline Cafeteria & n.a. & n.a. & 57.5 & 4.11 & [34] \\
\hline Houses & 12.24 & 18.30 & 42.78 & 2.85 & This work \\
\hline Houses & 12.24 & 18.30 & 34.85 & 2.32 & This work \\
\hline
\end{tabular}

Both soluble sugars and starch; n.a., not available.

As has been previously discussed cellulose hydrolysis reached $50.27 \%$ of the initial presented cellulose in HFW whereas the cellulose content of residue was $14.75 \% \mathrm{w} / \mathrm{w}$. During the hydrothermal pretreatment process $42.73 \%$ of the initial mass of the residue was solubilized. Cellulose content of the pretreated residue was $16.31 \%$, indicating a $36.68 \%$ of cellulose solubilization during the pretreatment.

During fermentation of the pretreated residue at 35\% and $45 \% \mathrm{w} / \mathrm{v}$, maximum ethanol concentrations of $11.44 \mathrm{~g} / \mathrm{L}$ and $15.92 \mathrm{~g} / \mathrm{L}$, respectively, were observed after $15 \mathrm{~h}$ (Figure 3). Moreover, increasing substrate concentrations of the fermented residue was associated with an increase in ethanol productivity (Table 4). From the initial cellulosic fraction of the pretreated residue,
$42.67 \%$ was hydrolyzed. The obtained yields $\left(\mathrm{Y}_{\mathrm{p} / \mathrm{s}}\right)$ reached $0.423 \mathrm{~g} / \mathrm{g}$ and $0.458 \mathrm{~g} / \mathrm{g}$ at $35 \%$ and $45 \%$ DM respectively, which were almost identical with the yields obtained during fermentation of HFW.

\section{Overall ethanol yields}

Figure 4 presents the overall obtained ethanol yield after the fermentation of $1 \mathrm{~kg}$ of raw material using the twostage sequential fermentation procedure (concerning the fermentations at $45 \% \mathrm{DM}$ ). In the first stage, $95.07 \mathrm{~g}$ of ethanol and $617.2 \mathrm{~g}$ of residue were obtained. The remaining residue was hydrothermally pretreated and the solid fraction was $353.5 \mathrm{~g}$, whereas the other solids were dissolved to the liquid fraction. In the second stage after fermentation of the pretreated residue $12.51 \mathrm{~g}$ of ethanol

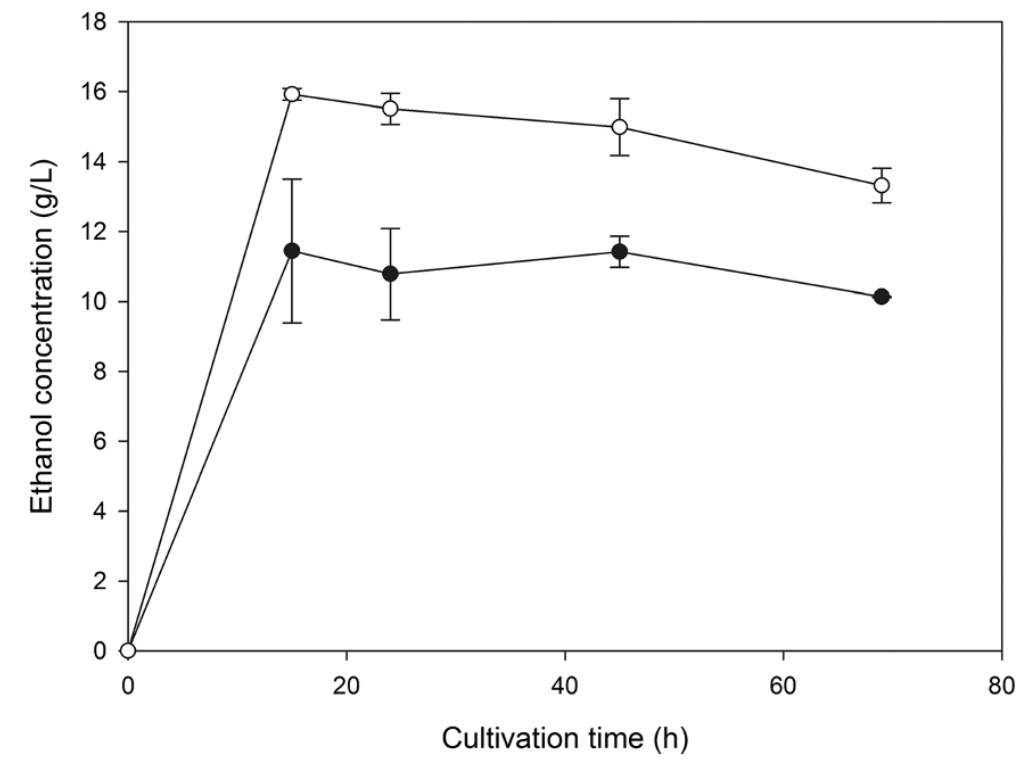

Figure 3 Production of ethanol from liquefied residue. Time course of ethanol production from hydrothermally pretreated residue at $35 \%$ (solid circles) and $45 \%$ (open circles) initial dry material content. 
Table 4 Results of ethanol production during cultivation of $S$. cerevisiae on pretreated residue

\begin{tabular}{cccc}
\hline $\begin{array}{c}\text { Initial DM } \\
(\% \mathbf{w} / \mathbf{v})\end{array}$ & $\begin{array}{c}\text { Ethanol } \\
\mathbf{( g / L )}\end{array}$ & $\begin{array}{c}\text { Productivity } \\
\mathbf{( g / L} \cdot \mathbf{h})\end{array}$ & $\begin{array}{c}\% \text { of } \\
\text { maximum } \\
\text { theoretical }\end{array}$ \\
\hline 35 & $11.44 \pm 1.45$ & $0.76 \pm 0.10$ & $35.34 \pm 4.49$ \\
45 & $15.92 \pm 0.12$ & $1.06 \pm 0.01$ & $38.23 \pm 0.28$ \\
\hline
\end{tabular}

could be obtained, thus the ethanol production yield could be increased from $95.07 \mathrm{~g} / \mathrm{kg}$ DM to $107.58 \mathrm{~g} / \mathrm{kg}$ DM, corresponding to an increase of $13.16 \%$. The ethanol yield comparing to the maximum theoretical increased from $57.12 \%$ to $63.64 \%$.

\section{Conclusions}

In the current work the potential of utilizing sourceseparated HFW for the production of ethanol at high DM content was demonstrated. A liquefaction process prior to fermentation increased both ethanol production and ethanol volumetric productivity. Finally the subsequent fermentation of residue increased the overall ethanol production yield.

\section{Methods}

\section{Raw material}

HFW utilized as raw material during this work were source-separated from houses in Papagos-Cholargos Municipality, Athens, Greece. The wastes were dried in situ in a prototype house dryer designed and developed by the Unit of Environmental Science and Technology (UEST), School of Chemical Engineering, NTUA [48]. Dried HFW were milled with a small laboratory mill at an average particle size less than $3 \mathrm{~mm}$. The composition of dried HFW is presented in Table 1.

\section{Reagents and enzyme solutions}

All chemicals were of analytical grade. During this work a mixture of the commercial enzyme solutions from Novozymes A/S (Bagsværd, Denmark) Celluclast ${ }^{\oplus} 1.5 \mathrm{~L}$ (cellulases) and Novozym 188 ( $\beta$-glucosidase) at a ratio of $5: 1 \mathrm{v} / \mathrm{v}$ has been applied for the liquefaction/saccharification process. The activity of the mixture was measured according to the standard filter paper assay [49] and found to be $83 \mathrm{FPU} / \mathrm{mL}$.

\section{Analytical methods}

Total reducing sugars were measured by the dinitro-3,5salicilic acid (DNS) method [50]. Monomeric sugars and ethanol were analyzed by HPLC (Shimadzu LC-20 AD, Kyoto, Japan) equipped with a refractive index detector (Shimadzu RID 10A, Kyoto, Japan). Monomeric sugar were analyzed utilizing an Aminex HPX-87P (300 × $7.8 \mathrm{~mm}$, particle size $9 \mu \mathrm{m}$, Bio-Rad, Hercules, California) chromatography column, operating at $70^{\circ} \mathrm{C}$ with HPLCwater as a mobile phase at a flow rate of $0.6 \mathrm{~mL} / \mathrm{minute}$. Ethanol was determined by an Aminex HPX-87H (300 × $7.8 \mathrm{~mm}$, particle size $9 \mu \mathrm{m}$, Bio-Rad, Hercules, California) chromatography column at $40^{\circ} \mathrm{C}$, with a mobile phase of $5 \mathrm{mM}$ sulfuric acid $\left(\mathrm{H}_{2} \mathrm{SO}_{4}\right)$ at a flow rate of $0.6 \mathrm{~mL} /$ minute.

Soluble fraction was analyzed according to the official method of the National Renewable Energy Laboratory (NREL) [51]. The liquid fraction was further analyzed for sugars and proteins [52]. Moisture was analyzed according to Sluiter et al. [53], whereas crude fat, ash, protein and total starch content determination were conducted according to standard Association of Official Agricultural Chemists (AOAC) methods [54]. Pectin was determined according to Phatak et al. [55]. Finally, the cellulose, hemicellulose and (acid-insoluble) lignin content was determined according to Sluiter et al. [53]. It is worth mentioning that the HFW utilized during this work had no starch content. Analysis was carried out in triplicate. Apparent viscosity of the HFW before and after enzymatic treatment was determined by an Anton Paar Physica MCR rheometer apparatus (Anton Paar $\mathrm{GmbH}$, Ashland, USA) as previously described [56].

\section{Hydrothermal pretreatment of residue}

The remaining solids after fermentation of HFW were hydrothermally pretreated by microwave digestion equipment at $200^{\circ} \mathrm{C}$ for 10 minutes as previously described [41]. After the pretreatment, the solids were removed from the liquid fraction through vacuum filtration and washed in order to remove inhibitors formed during pretreatment. Finally, solids were dried at $60^{\circ} \mathrm{C}$ until constant weight reached.

\section{Enzymatic liquefaction and saccharification of HFW}

Enzymatic liquefaction/saccharification of untreated HFW and hydrothermally pretreated residue was conducted in a liquefaction reactor which was designed and manufactured in-house. More specifically, the reactor consists of two vertical cylindrical chambers which are $6 \mathrm{~cm}$ wide and $25 \mathrm{~cm}$ diameter, with a rotating shaft driven by a $0.37-\mathrm{kW}$ motor for the mixing of the material. The mixing shaft was programmed to shift from clockwise to anticlockwise rotation every minute in order to achieve better mixing. Finally, the temperature was controlled by an external oil jacket.

The liquefaction/saccharification process was performed at initial DM concentration of $45 \% \mathrm{w} / \mathrm{v}$ for $8 \mathrm{~h}$. The $\mathrm{pH}$ was adjusted to 5.0 by using $50 \mathrm{mM}$ citrate-phosphate buffer and the enzyme load applied was $10 \mathrm{FPU} / \mathrm{g}$ DM. Finally, the temperature of the liquefaction/saccharification was set at $50^{\circ} \mathrm{C}$. At the end of the liquefaction/saccharification 
Figure 4 Overall ethanol production yield. Ethanol production yield after fermentation of liquefied household food wastes (HFW) at initial dry material (DM) content of $45 \%$ and subsequent fermentation of the residue. Prior to fermentation, residue was hydrothermally pretreated at $200^{\circ} \mathrm{C}$ for 10 minutes and liquefied.

process the whole slurry (also containing unhydrolyzed solids) was utilized for the fermentation experiments.

\section{Ethanol fermentation}

Fermentations at 35\% and 45\% (w/v) DM of non-sterilized liquefied HFW or pretreated residue were performed in 100 -mL Erlenmeyer flasks in an orbital shaker at $30^{\circ} \mathrm{C}$ with an agitation of $100 \mathrm{rpm}$. The fermenting microorganism was dry baker's yeast (Yiotis, Athens, Greece), which was added at a concentration corresponding to $15 \mathrm{mg} / \mathrm{g}$ of initial DM. To evaluate the importance of the separate liquefaction/saccharification step, untreated HFW were fermented under the same conditions. Samples were taken at certain time intervals, centrifuged and analyzed for ethanol. All trials were carried out in duplicate.

When the HFW fermentation process was completed, the broth was filtrated under vacuum in order to remove the solids which were further washed with distilled water. The solids (residue) were dried at $60^{\circ} \mathrm{C}$ until constant weight reached and were further utilized for ethanol production after being hydrothermally pretreated (as previously described).

\section{Abbreviations}

DM: Dry material; HFW: Household food wastes; HPLC: High performance liquid chromatography.

\section{Competing interests}

The authors declare that they have no competing interests.

\section{Authors' contributions}

All authors ( $L M, D K, M L$ and $P C)$ contributed jointly to all aspects of the work reported in the manuscript. All authors have read and approved the final manuscript.

\section{Acknowledgements}

This work is based on the research that was carried out in the framework of a LIFE + project entitled: Development and demonstration of an innovative method of converting waste into bioethanol, Waste2Bio, (LIFE 11 ENV/GR/ 000949, 2012-2015), which is co-financed by the European Commission. Paul Christakopoulos thanks Bio4Energy, a strategic research environment appointed by the Swedish government, for supporting this work.

\footnotetext{
Author details

${ }^{1}$ Biotechnology Laboratory, School of Chemical Engineering, National Technical University of Athens, 5 Iroon Polytechniou Str, Zografou Campus, 15780 Athens, Greece. ${ }^{2}$ Unit of Environmental Science and Technology, School of Chemical Engineering, National Technical University of Athens, 5, Iroon Polytechniou Str, Zografou Campus, 15780 Athens, Greece. ${ }^{3}$ Department of Civil, Biochemical and Chemical Process Engineering, Division of Sustainable Process Engineering, Environmental and Natural Resources Engineering, Luleå University of Technology, SE 97187 Luleå, Sweden.
} 


\section{References}

1. Li X, Kim TH, Nghiem NP: Bioethanol production from corn stover using aqueous ammonia pretreatment and two-phase simultaneous saccharification and fermentation (TPSSF). Bioresour Technol 2010, 101:5910-5916.

2. Sarris D, Giannakis M, Philippoussis A, Komaitis M, Koutinas AA, Papanikolaou S: Conversions of olive mill wastewater-based media by Saccharomyces cerevisiae through sterile and non-sterile bioprocesses. J Chem Technol Biotechnol 2013, 88:958-969.

3. Matsakas $\mathrm{L}$, Christakopoulos P: Optimization of ethanol production from high dry matter liquefied dry sweet sorghum stalks. Biomass Bioenerg 2013, 51:91-98.

4. Yan S, Chen X, Wu J, Wang P: Ethanol production from concentrated food waste hydrolysates with yeast cells immobilized on corn stalk. Appl Microbiol Biotechnol 2012, 94:829-838.

5. Sims REH, Mabee W, Saddler JN, Taylor M: An overview of second generation biofuel technologies. Bioresour Technol 2010, 101:1570-1580.

6. Moon HC, Song IS, Kim JC, Shirai Y, Lee DH, Kim JK, Chung SO, Kim DH, Oh KK, Cho YS: Enzymatic hydrolysis of food waste and ethanol fermentation. Int J Energ Res 2009, 33:164-172.

7. Zhang M, Wang F, Su R, Qi W, He Z: Ethanol production from high dry matter corncob using fed-batch simultaneous saccharification and fermentation after combined pretreatment. Bioresour Technol 2010, 101:4959-4964.

8. Silva VN, Arruda P, Felipe MA, Gonçalves A, Rocha GM: Fermentation of cellulosic hydrolysates obtained by enzymatic saccharification of sugarcane bagasse pretreated by hydrothermal processing. I Ind Microbiol Biotechnol 2011, 38:809-817.

9. Díaz MJ, Cara C, Ruiz E, Romero I, Moya M, Castro E: Hydrothermal pre-treatment of rapeseed straw. Bioresour Technol 2010, 101:2428-2435.

10. Pérez JA, Ballesteros I, Ballesteros M, Sáez F, Negro MJ, Manzanares P: Optimizing liquid hot water pretreatment conditions to enhance sugar recovery from wheat straw for fuel-ethanol production. Fuel 2008, 87:3640-3647.

11. European Communities: EC preparatory study on food waste in the EU27. [http://ec.europa.eu/environment/eussd/pdf/bio foodwaste_report.pdf]

12. Yan S, Li J, Chen X, Wu J, Wang P, Ye J, Yao J: Enzymatical hydrolysis of food waste and ethanol production from the hydrolysate. Renew Energ 2011, 36:1259-1265.

13. Lin CSK, Pfaltzgraff LA, Herrero-Davila L, Mubofu EB, Abderrahim S, Clark JH, Koutinas AA, Kopsahelis N, Stamatelatou K, Dickson F, Thankappan S, Mohamed Z, Brocklesby R, Luque R: Food waste as a valuable resource for the production of chemicals, materials and fuels. Current situation and global perspective. Energ Environ Sci 2013, 6:426-464.

14. Uncu ON, Cekmecelioglu D: Cost-effective approach to ethanol production and optimization by response surface methodology. Waste Manage 2011, 31:636-643.

15. Luque R, Clark J: Valorisation of food residues: waste to wealth using green chemical technologies. Sustain Chem Process 2013, 1:10.

16. Arancon RAD, Lin CSK, Chan KM, Kwan TH, Luque R: Advances on waste valorization: new horizons for a more sustainable society. Energ Sci Eng 2013, 1:53-71

17. Jensen JW, Felby C, Jørgensen H, Rønsch GØ, Nørholm ND: Enzymatic processing of municipal solid waste. Waste Manage 2010, 30:2497-2503.

18. Ma J, Duong TH, Smits M, Verstraete W, Carballa M: Enhanced biomethanation of kitchen waste by different pre-treatments. Bioresour Technol 2011, 102:592-599.

19. Singhal S, Bansal SK, Singh R: Evaluation of biogas production from solid waste using pretreatment method in anaerobic condition. Int J Emerg Sci 2012, 2:405-414

20. Vavouraki Al, Angelis EM, Kornaros M: Optimization of thermo-chemical hydrolysis of kitchen wastes. Waste Manage 2013, 33:740-745.

21. Singhania RR, Patel AK, Soccol CR, Pandey A: Recent advances in solid-state fermentation. Biochem Eng J 2009, 44:13-18.

22. Jørgensen $\mathrm{H}$, Vibe-Pedersen J, Larsen J, Felby C: Liquefaction of lignocellulose at high-solids concentrations. Biotechnol Bioeng 2007, 96:862-870.

23. Larsen J, Østergaard Petersen M, Thirup L, Wen Li H, Krogh Iversen F: The IBUS process - lignocellulosic bioethanol close to a commercial reality. Chem Eng Technol 2008, 31:765-772.
24. Bernstad A, Malmquist L, Truedsson C, la Cour Jansen J: Need for improvements in physical pretreatment of source-separated household food waste. Waste Manage 2013, 33:746-754.

25. Kim JH, Lee JC, Pak D: Feasibility of producing ethanol from food waste. Waste Manage 2011, 31:2121-2125.

26. Le Man H, Behera SK, Park HS: Optimization of operational parameters for ethanol production from Korean food waste leachate. Int J Environ Sci Tech 2010, 7:157-164.

27. Zhang $X$, Richard T: Dual enzymatic saccharification of food waste for ethanol fermentation. In Proceedings of international conference on electrical and control engineering: 16-18 September 2011; Yichang. ISBN 978-1-4244-8162-0.

28. Szijarto N, Horan E, Zhang J, Puranen T, Siika-aho M, Viikari L: Thermostable endoglucanases in the liquefaction of hydrothermally pretreated wheat straw. Biotechnol Biofuels 2011, 4:2.

29. Manzanares P, Negro MJ, Oliva JM, Saéz F, Ballesteros I, Ballesteros M, Cara C, Castro E, Ruiz E: Different process configurations for bioethanol production from pretreated olive pruning biomass. J Chem Technol Biotechnol 2011, 86:881-887.

30. Hoyer K, Galbe M, Zacchi G: Production of fuel ethanol from softwood by simultaneous saccharification and fermentation at high dry matter content. J Chem Technol Biotechnol 2009, 84:570-577.

31. Walker K, Vadlani P, Madl R, Ugorowski P, Hohn KL: Ethanol fermentation from food processing waste. Environ Prog Sustain Energ 2012, 32:1280-1283

32. Jeong S-M, Kim Y-J, Lee D-H: Ethanol production by co-fermentation of hexose and pentose from food wastes using Saccharomyces coreanus and Pichia stipitis. Korean J Chem Eng 2012, 29:1038-1043.

33. Cekmecelioglu D, Uncu ON: Kinetic modeling of enzymatic hydrolysis of pretreated kitchen wastes for enhancing bioethanol production. Waste Manage 2013, 33:735-739.

34. Kim JK, Oh BR, Shin H-J, Eom C-Y, Kim SW: Statistical optimization of enzymatic saccharification and ethanol fermentation using food waste. Process Biochem 2008, 43:1308-1312.

35. Tang Y-Q, Koike Y, Liu K, An M-Z, Morimura S, Wu X-L, Kida K: Ethanol production from kitchen waste using the flocculating yeast Saccharomyces cerevisiae strain KF-7. Biomass Bioenerg 2008, 32:1037-1045.

36. Dererie DY, Trobro S, Momeni MH, Hansson H, Blomqvist J, Passoth V, Schnürer A, Sandgren M, Ståhlberg J: Improved bio-energy yields via sequential ethanol fermentation and biogas digestion of steam exploded oat straw. Bioresour Technol 2011, 102:4449-4455.

37. Bauer A, Bösch P, Friedl A, Amon T: Analysis of methane potentials of steam-exploded wheat straw and estimation of energy yields of combined ethanol and methane production. J Biotechnol 2009, 142:50-55.

38. Kaparaju P, Serrano M, Thomsen AB, Kongjan P, Angelidaki I: Bioethanol, biohydrogen and biogas production from wheat straw in a biorefinery concept. Bioresour Technol 2009, 100:2562-2568.

39. Bondesson PM, Galbe G, Zacchi G: Ethanol and biogas production after steam pretreatment of corn stover with or without the addition of sulphuric acid. Biotechnol Biofuels 2013, 6:11

40. Xiros C, Katapodis P, Christakopoulos P: Evaluation of Fusarium oxysporum cellulolytic system for an efficient hydrolysis of hydrothermally treated wheat straw. Bioresour Technol 2009, 100:5362-5365.

41. Matsakas L, Christakopoulos P: Fermentation of liquefacted hydrothermally pretreated sweet sorghum bagasse to ethanol at high-solids content. Bioresour Technol 2013, 127:202-208.

42. Petrik $S$, Kádár Z, Márová I: Utilization of hydrothermally pretreated wheat straw for production of bioethanol and carotene-enriched biomass. Bioresour Technol 2013, 133:370-377.

43. da Cunha-Pereira F, Hickert LR, Sehnem NT, de Souza-Cruz PB, Rosa CA, Ayub MAZ: Conversion of sugars present in rice hull hydrolysates into ethanol by Spathaspora arborariae, Saccharomyces cerevisiae, and their co-fermentations. Bioresour Technol 2011, 102:4218-4225.

44. Alvira P, Moreno AD, Ibarra D, Sáez F, Ballesteros M: Improving the fermentation performance of Saccharomyces cerevisiae by laccase during ethanol production from steam-exploded wheat straw at high-substrate loadings. Biotechnol Prog 2013, 29:74-82.

45. Geddes CC, Peterson JJ, Roslander C, Zacchi G, Mullinnix MT, Shanmugam KT, Ingram LO: Optimizing the saccharification of sugar cane bagasse using dilute phosphoric acid followed by fungal cellulases. Bioresour Technol 2010, 101:1851-1857. 
46. Palmqvist $E$, Hahn-Hägerdal B: Fermentation of lignocellulosic hydrolysates. II: inhibitors and mechanisms of inhibition. Bioresour Technol 2000, 74:25-33.

47. Klinke $H B$, Thomsen $A B$, Ahring $B K$ : Inhibition of ethanol-producing yeast and bacteria by degradation products produced during pre-treatment of biomass. Appl Microbiol Biotechnol 2004, 66:10-26.

48. LIFE 08/ENV/GR/000566. [http://www.uest.gr/drywaste/site/index.htm]

49. Ghose TK: Measurement of cellulase activities. Pure Appl Chem 1987, 59:257-268.

50. Miller GL: Use of dinitrosalicylic acid reagent for determination of reducing sugar. Anal Chem 1959, 31:426-428.

51. Sluiter A, Ruiz R, Scarlata C, Sluiter J, Templeton D: Determination of Extractives in Biomass. Technical report NREL/TP-510-42619, Laboratory analytical protocol. Golden CO: National Renewable Energy Laboratory; 2008.

52. Bradford MM: A rapid and sensitive method for the quantification of microgram quantities of protein utilizing the principle of protein-dye binding. Anal Biochem 1976, 72:248-254.

53. Sluiter A, Hames B, Ruiz R, Scarlata C, Sluiter J, Templeton D, Crocker D: Determination of structural carbohydrates and lignin biomass. Technical report NREL/TP-510-42618, Laboratory analytical protocol. Golden CO: National Renewable Energy Laboratory; 2012.

54. William H: Official methods of analysis of the association of official analytical chemists. Washigton DC: AOAC Inc; 1970.

55. Phatak L, Chang KC, Brown G: Isolation and characterization of pectin in sugar-beet pulp. J Food Sci 1988, 53:830-833.

56. Karnaouri AC, Topakas E, Christakopoulos P: Cloning, expression, and characterization of a thermostable GH7 endoglucanase from Myceliophthora thermophila capable of high-consistency enzymatic liquefaction. Appl Microbiol Biotechnol 2013. in press.

doi:10.1186/1754-6834-7-4

Cite this article as: Matsakas et al:: Utilization of household food waste for the production of ethanol at high dry material content. Biotechnology for Biofuels 2014 7:4.

\section{Submit your next manuscript to BioMed Central and take full advantage of:}

- Convenient online submission

- Thorough peer review

- No space constraints or color figure charges

- Immediate publication on acceptance

- Inclusion in PubMed, CAS, Scopus and Google Scholar

- Research which is freely available for redistribution 